\title{
Evaluation of the self-eye examination method for health promotion*
}

\author{
Avaliação do método de autoexame ocular para a promoção da saúde \\ Evaluación del método de autoexamen ocular para promoción de la salud
}

\author{
Maria Alzete de Lima1, Jennara Candido do Nascimento², Abel Brasil Ramos da Silva ${ }^{3}$, Lívia Moreira Barros ${ }^{4}$, Lorita \\ Marlena Freitag Pagliuca ${ }^{5}$, Joselany Áfio Caetano ${ }^{5}$
}

How to cite this article:

Lima MA, Nascimento JC, Silva ABR, Barros LM, Pagliuca LMF, Caetano JA. Evaluation of the self-eye examination method for health promotion. Rev Esc Enferm USP. 2018;52:e03340. DOI: http://dx.doi.org/10.1590/S1980-220X2017003803340

\author{
* Extracted from the thesis: "Aplicação da \\ cartilha virtual sobre autoexame ocular: uma \\ perspectiva de aprendizagem significativa”, \\ Programa de Pós-Graduação em Enfermagem, \\ Universidade Federal do Ceará, 2014. \\ ${ }^{1}$ Universidade Federal do Rio Grande do Norte, \\ Departamento de Enfermagem, Natal, RN, Brazil. \\ ${ }^{2}$ Centro Universitário Estácio do \\ Ceará, Departamento de Enfermagem, \\ Fortaleza, CE, Brazil. \\ ${ }^{3}$ Universidade Federal do Ceará, Departamento \\ de Estatística, Fortaleza, CE, Brazil. \\ ${ }^{4}$ Universidade Estadual Vale \\ do Acaraú, Departamento de \\ Enfermagem, Sobral, CE, Brazil. \\ ${ }^{5}$ Universidade Federal do Ceará, \\ Programa de Pós-Graduação em \\ Enfermagem, Fortaleza, CE, Brazil.
}

\section{Corresponding author:}

Maria Alzete de Lima

Rua Desportista Jeremias Pinheiro

da Câmara Filho, 270, Ap. 1607

Condomínio Royal Park, Bloco B, Ponta Negra

CEP 59091-250 - Natal, RN, Brazil

alzetelima@yahoo.com.br

\begin{abstract}
Objective: To evaluate the self-eye examination practice as a tool to promote the ocular self-evaluation. Method: Quasi-experimental study developed in a university of Piauí with sample of 324 students between January and May 2014. A team of thirteen researchers made observations during the self-examination followed by an ocular screening. Results: There was no agreement on the hypothesis of defense that the ocular exam could help to observe the eyes health, $\mathrm{p}$-value $>0.3$. However, the exam was considered as easy to accomplish (99.7\%) and that not only the physician can perform the eye exam (99.4\%). The awareness about eye care is identified as the main purpose of this booklet $(97.6 \%),\left(\chi^{2}=186.01 ; p=0.001\right)$. The results highlight the booklet can be used in the teaching process of self-eye examination (84.6\%). Although the defense that its fulfilment can replace the consultation with the ophthalmologist $(23.8 \% \%)$ cannot be accepted $\left(\chi^{2}=46.34\right)$, the self-exam must be done routinely $(82.4 \%)$. Conclusion: The results prove that the learning through virtual booklet is possible and supports self-care with the eyes by performing the self-exam.
\end{abstract}

\section{DESCRIPTORS}

Eye; Eye Health; Self-Examination; Health Education; Public Health Nursing. 


\section{INTRODUCTION}

Even though the world prevalence of blindness has decreased from $0.60 \%$ in 1990 to $0.47 \%$ in 2010 , the global estimation is of 32.4 million blind people. Reasons leading to visual disorders are multiple and frequently associated to biological, social and ecological factors that can be prevented or alleviated ${ }^{(1)}$. Glaucoma connected to genetic factors, loss of visual capacity arising from senility, macular degeneration, which is the main reason of blindness all over the world, and as prevalent as cancer in industrialized nations, are examples denoting public health problems ${ }^{(2-4)}$.

In countries of low and average income, where access to ocular health services is still unequal, the estimated occurrence of visual deficiency cases is $90 \%$. This reminds of the need for practical tools enabling the early detection of ocular diseases and adequate referral to specialized services ${ }^{(5-6)}$.

Therefore, prevention and health promotion actions of ophthalmological problems are crucial for changing the epidemiological profile of ocular diseases. Among these actions, those with the aim to increase the population's knowledge about feasible steps and early identification of the need for searching specialized care stand out.

When evaluating eye self-examination methods, strategies to help clinical practice by stimulating early diagnosis are created. At the same time, when acquiring autonomy in the judgment on the real health condition and seeking specialized care services, opportune strategies in educational actions and care promoters can be decisive for maintaining subjects' ocular health ${ }^{(7-8)}$.

Within this context, several scenarios can serve as favorable environment for ocular health promotion through meddlesome and educational actions, and use of various educational technologies. Among the assets, the ocular self-exam practice is prominent, because it encourages the empowerment of individuals and collectives in relation to eye care $^{(7)}$. Therefore, the aim of this study is to evaluate the self-examination practice as a tool to promote ocular self-assessment.

\section{METHOD}

Quasi-experimental, prospective study performed in a university in Piauí state, Brazil, from January to May of 2014. The population were 2,060 regularly enrolled students, who were attending class between the first and last period. The sample calculation was used for a limited population by considering a confidence level of $95 \%$ and sampling error of 5\%. Thereby, the sample was composed of 324 students. The inclusion criteria were physical condition to execute the ocular self-exam, and a basic domain of computer use. Students from distance learning courses, diagnosed with visual problems and those who had already taken a course in semiology were excluded. Regularly sampled students enrolled in the daytime period of all faceto-face courses formed the sample, which was proportional and stratified for each course.

Data collection occurred in three moments, namely: educational intervention mediated by use of a virtual booklet for ocular self-examination; observation of the steps of automatic examination and eye exam by trained staff; perception about performing ocular evaluation after using the virtual booklet.

The first moment of the study was the implementation of the educational strategy with use of the virtual booklet for ocular self-exam, and the investigation of the population's ocular health conditions. In short, physical examination of the visual system in easy steps to be performed, which includes visual acuity evaluation (far and near), external ocular structures evaluation (conjunctive, sclera, eyelid, and eyelashes), visual field evaluation (peripheral and central vision), and ocular movement.

Students were invited in two ways; through visits in classrooms and by e-mail. They were enlightened about the purposes, risks and benefits associated with their participation in the study. After their approval, was scheduled the day, time and place where the ocular self-exam would be held. This information was sent to participants by email.

On the appointed day, activities were accomplished in the clinical practice laboratory of the university. It was equipped with a computer connected to the internet, where the website could be accessed only at the time of this study. Free access was withdrawn in order to follow patent process, and use the virtual booklet for ocular self-exam. The collection team included two nurses and 13 nursing students who were previously trained in a 20 hour-course on sight classification.

As a way to standardize collection and ensure fidelity in clinical judgment, 12 hours of the course were simulated in pairs with observation and exam performance in participants invited to the pilot study phase.

For this moment, were used the collection instrument and the ocular evaluation scale applied by each participant and then, by the researcher. After comparing and discussing the results of possible divergent judgments, were calibrated the ways of measuring, which in the case of this study is the application of evaluation form by the judge. Therefore, everyone had the same understanding about what was considered normal or changed, appropriate or inappropriate.

There were repeated simulations with different participants that were subject to comparison until there were no divergences, that is, a consensus was reached on clinical judgment. At the end of the course, team members underwent final test judging evaluations on three different subjects. All pilot study data (foreseen in the project) were excluded from the study sample.

The second moment of the study was the observation of stages of self-examination by the researchers and the retest. On the phase that participants accomplished the ocular selfexam steps, a sampling team member was responsible for the observation and for recording the students' performance as they accomplished the self-examination steps. This allowed the verification of the appropriateness of the method to the virtual booklet recommendations. 
At the end, all participants took a retest. It was evaluated by a member of the team who was previously trained in all five steps composing the ocular self-exam. Results were recorded on a form with a Likert's scale composed of the following five items: totally adequate (5), adequate (4), partially adequate (3), inadequate (2) and totally inadequate (1).

The observation results were confronted and when reaching consensus, the surveys were double typed in an Excel sheet and analysis was performed by using the SPSS (Statistical Package for the Social Sciences) version 20.0. Thus, the spectrum bias was reduced and a larger specificity and inter-observer reliability were granted because of the impossibility of double blinding. The third moment included perception about the fulfilment of the ocular evaluation after using the virtual booklet.

Therefore, the study intervention was the accomplishment of the ocular examination by the individual him/ herself using virtual educational material containing the appropriate steps for self-examination. The result of the self-assessment was then compared to the examination conducted by the researcher and his trained team with use of printed scales.

The interest hypothesis is that the study participant accomplishes the ocular self-exam by using the virtual educative material and following the same steps envisioned by the literature. The Chi-Square test was used for the comparative performance analysis, and a significance level of $5 \%$ was adopted. This association was determined as a statistical method in order to prove the occurrence of a significant learning.

The development of the study was in accordance with international principles of research on human beings. The study was approved by the Research Ethics Committee under number 508.069. Students received information and signed the Informed Consent form.

\section{RESULTS}

The 324 students of the sample were predominantly youngsters with average age of 21 years (deviation of 3.3 years). The coefficient of variation was low (15.5\%), which shows a uniform distribution of this variable.

Regarding perception on ocular health, most participants stated they knew at least one visual disorder $(69.8 \%)$, and mentioned mainly the refractive error (54\%), followed by cataract (27.2\%). The search intention with the aforementioned findings was the identification of previous knowledge, i.e., the presence of relevant concepts or anchors before the contact with educational material.

After reading the educational material and doing the ocular self-exam, participants believed the periodic ocular evaluation was also useful for people without any vision disorder $(98.5 \%)$, and this confirms the preventive awareness character of the self-exam method (Table 1).
There was no consensus about defending the hypothesis that the eye exam could help to check the eyes health, $\mathrm{p}$-value $>0.3$. However, the eye exam was considered easy to perform (99.7\%) and possible to be done not only by the doctor (99.4\%) (Table 1).

Table 1 - Participants distribution according to perception of the ocular evaluation fulfilment after using the virtual booklet - Piauí, Brazil, 2014.

\begin{tabular}{lccc}
\hline & Yes & No & \multirow{2}{*}{ p-value } \\
\cline { 2 - 3 } & $\mathbf{n}(\%)$ & $\mathbf{n}(\%)$ & \\
\hline Seeks for doctor if any disorder is found & $95(29.3)$ & $229(70.7)$ & $<0.001$ \\
Checks if the person is seeing well & $64(19.8)$ & $260(80.2)$ & $<0.001$ \\
Useful only for those with vision problems & $5(1.5)$ & $319(98.5)$ & $<0.001$ \\
Helps to observe the eye's health & $170(52.5)$ & $154(47.5)$ & 0.374 \\
Thinks it is complicated to do the & $1(0.3)$ & $323(99.7)$ & $<0.001$ \\
ocular self-exam & $2(0.6)$ & $322(99.4)$ & $<0.001$ \\
Only the doctor can examine the eyes & 2 & &
\end{tabular}

Note: $\mathrm{n}=324$.

The awareness about eye care was pointed as the main purpose of the booklet $(97.6 \%)\left(\chi^{2}=186.01 ; p=0.001\right)$, which confirms the investigated hypothesis. The results highlight that the booklet can be used in the teaching process of the eye self-exam (84.6\%). However, the defense that performing the eye self-exam can replace the consultation with an ophthalmologist $(23.8 \%),\left(\chi^{2}=46.34\right)$ cannot be accepted.

Therefore, the existence of no direct relationship between the performance of self-exam and the low demand for specialists is clear. Even so, the self-exam can be done regularly (82.4\%). The evaluation of results on the virtual booklet organization and its adequacy to users demonstrates that the material fulfils the educational precepts that promote learning (Table 2).

Table 2 - Data distribution according to evaluation on the booklet use - Piauí, Brazil, 2014.

\begin{tabular}{|c|c|c|c|}
\hline & $\begin{array}{l}\text { Agree } \\
\text { n (\%) }\end{array}$ & $\begin{array}{l}\text { Disagree } \\
\text { n }(\%)\end{array}$ & $\chi^{2}$ \\
\hline \multicolumn{4}{|l|}{ Purpose of the booklet use } \\
\hline $\begin{array}{l}\text { Helps to raise the awareness } \\
\text { about eye care }\end{array}$ & 315 (97.6) & $8(2.5)$ & 186.01 \\
\hline Informs how to do the self-exam & $273(84.6)$ & $50(15.4)$ & 85.83 \\
\hline Brings new knowledge about eye care & $270(83.6)$ & $53(16.7)$ & 80.66 \\
\hline $\begin{array}{l}\text { Does not replace consultation with } \\
\text { the ophthalmologist }\end{array}$ & $246(76.2)$ & $77(23.8)$ & 46.34 \\
\hline $\begin{array}{l}\text { Ocular self-exam must } \\
\text { be done regularly }\end{array}$ & $266(82.4)$ & $57(17.6)$ & 74.08 \\
\hline \multicolumn{4}{|l|}{ Organization } \\
\hline $\begin{array}{l}\text { It is organized on a clear } \\
\text { and logical way }\end{array}$ & $305(94.4)$ & $18(5.6)$ & 156.65 \\
\hline The virtual booklet is easy to find & $308(95.4)$ & $15(4.6)$ & 165.03 \\
\hline The materials used are easy to find & $319(98.8)$ & $4(1.2)$ & 198.96 \\
\hline \multicolumn{4}{|l|}{ Booklet adequacy to user } \\
\hline $\begin{array}{l}\text { Format/introduction of } \\
\text { the booklet promotes learning }\end{array}$ & $309(95.4)$ & $15(4.6)$ & 165.03 \\
\hline Steps are easy to take & $306(94.5)$ & $18(5.5)$ & 156.65 \\
\hline Language is simple & $313(96.6)$ & $11(3.4)$ & 176.77 \\
\hline
\end{tabular}

$\chi^{2}$ : Chi-square; $\mathrm{p}$-value for all variables was $<0.001$. Note: $\mathrm{n}=324$. 
In the ocular self-exam process, the results point to an adequacy to the visual acuity evaluation. Except for the steps of hand sanitizing $(16.3 \%)$ and the Snellen scale positioning (44.4\%), all other items had a percentage above $50 \%$ in the totally adequate concept (Table 3).

Table 3 - Synthesis of results of the eye self-exam observation held by the student regarding the environment and visual acuity, Piauí, Brazil, 2014.

\begin{tabular}{|c|c|c|c|c|c|c|}
\hline & $\begin{array}{c}\text { TI } \\
\text { n (\%) }\end{array}$ & $\begin{array}{c}\text { I } \\
\text { n (\%) }\end{array}$ & $\begin{array}{c}\text { A } \\
\text { n (\%) }\end{array}$ & $\begin{array}{c}\text { PA } \\
\text { n (\%) }\end{array}$ & $\begin{array}{c}\text { TA } \\
\text { n (\%) }\end{array}$ & $\chi^{2}$ \\
\hline \multicolumn{7}{|l|}{ Care before the exam } \\
\hline Hand sanitizing & $158(48.8)$ & $85(26.2)$ & $26(8.0)$ & $3(0.9)$ & $52(16.1)$ & 45.81 \\
\hline Preparation of the place & $2(0.6)$ & $21(6.5)$ & $61(18.8)$ & $70(21.6)$ & $170(52.5)$ & 144.07 \\
\hline \multicolumn{7}{|l|}{ Long distance vision } \\
\hline Snellen scale use & $20(6.2)$ & $32(9.9)$ & $57(17.6)$ & $71(21.9)$ & $144(44.4)$ & 82.89 \\
\hline Scale's distance & $11(3.4)$ & $22(6.8)$ & $14(4.3)$ & $62(19.1)$ & $215(66.4)$ & 120.19 \\
\hline Examination of each eye & $6(1.8)$ & $16(4.9)$ & $12(3.7)$ & $41(12.7)$ & $249(76.9)$ & 146.65 \\
\hline \multicolumn{7}{|l|}{ Near distance vision } \\
\hline Snellen scale use & $12(3.7)$ & $17(5.2)$ & $38(11.7)$ & $48(14.8)$ & $209(64.6)$ & 129.35 \\
\hline Use of glasses & $7(2.2)$ & $13(4.0)$ & $4(1.2)$ & $23(7.1)$ & $277(85.5)$ & 151.90 \\
\hline Examination of each eye & $7(2.2)$ & $16(4.9)$ & $12(3.7)$ & $42(13.0)$ & $247(76.2)$ & 144.07 \\
\hline \multicolumn{7}{|l|}{ Peripheral vision } \\
\hline Occlusion of each eye & $3(0.9)$ & $4(1.2)$ & $10(3.1)$ & $34(10.5)$ & $273(84.3)$ & 189.84 \\
\hline Brings newspaper closer & $2(0.6)$ & $10(3.1)$ & $13(4.0)$ & $44(13.6)$ & $255(78.7)$ & 174.43 \\
\hline Observation of changes & $7(2.2)$ & $15(4.6)$ & $19(5.9)$ & $51(15.7)$ & $232(71.6)$ & 146.65 \\
\hline Examination of each eye & $8(2.5)$ & $11(3.4)$ & $12(3.7)$ & $36(11.1)$ & $257(79.3)$ & 154.58 \\
\hline \multicolumn{7}{|l|}{ Central vision } \\
\hline Position the scale & $13(4.0)$ & $28(8.6)$ & $19(5.9)$ & $79(24.4)$ & $185(57.1)$ & 103.30 \\
\hline Ocular occlusion & $13(4.0)$ & $6(1.8)$ & $8(2.5)$ & $41(12.7)$ & $256(79.0)$ & 154.58 \\
\hline Check lines on the scale & $10(3.1)$ & $3(0.9)$ & $13(4.0)$ & $55(17.0)$ & $243(75.0)$ & 171.47 \\
\hline Examination of each eye & $8(2.5)$ & $7(2.2)$ & $17(5.2)$ & $44(13.6)$ & $248(76.5)$ & 165.69 \\
\hline
\end{tabular}

$\chi^{2}$ : Chi-square; $\mathrm{p}$ value for all variables was $<0.005$. TI: Totally inadequate; I: Inadequate; A: Adequate; PA: Partially adequate; TA: Totally adequate. Note: $\mathrm{n}=324$.

Comparatively analyzing the performance of visual acuity self-exam for near distances, a similar result is found. Therefore, the void hypothesis is accepted, and there is the need of adjustment of data on the correct use of the scale for visual acuity evaluation on the virtual booklet.
In the structure of the eye exam, the record of adequacy to method reached $82.7 \%$. The conjunctive exam was that of less reliability, in which there was inadequacy of eyelids inversion (19.1\%) and identification of symptoms (22.2\%). However, there is no evidence of this finding compromising the ocular evaluation result (Table 4).

Table 4 - Synthesis of results of the eye self-exam observation held by the student regarding the ocular structure exam - Piauí, Brazil, 2014.

\begin{tabular}{|c|c|c|c|c|c|c|}
\hline & $\begin{array}{c}\text { TI } \\
\text { n (\%) }\end{array}$ & $\begin{array}{c}\text { I } \\
\text { n (\%) }\end{array}$ & $\begin{array}{c}\text { A } \\
\text { n (\%) }\end{array}$ & $\begin{array}{c}\text { PA } \\
\text { n (\%) }\end{array}$ & $\begin{array}{c}\text { TA } \\
\text { n (\%) }\end{array}$ & $\chi^{2}$ \\
\hline \multicolumn{7}{|l|}{ Eyelid } \\
\hline Uses mirror & $4(1.2)$ & $19(5.9)$ & $4(1.2)$ & $29(9.0)$ & $268(82.7)$ & 144.07 \\
\hline Identifies changes & $9(2.8)$ & $26(8.0)$ & $33(10.2)$ & $52(16.0)$ & $204(63.0)$ & 115.79 \\
\hline Examines each eye & $5(1.5)$ & $23(7.1)$ & $11(3.4)$ & $48(14.8)$ & $237(73.2)$ & 131.72 \\
\hline \multicolumn{7}{|l|}{ Conjunctive } \\
\hline Examines conjunctive & $7(2.2)$ & $35(10.8)$ & $23(7.1)$ & $39(12.1)$ & $220(67.8)$ & 101.31 \\
\hline Reverses the eyelid & $14(4.3)$ & $48(14.8)$ & $45(13.9)$ & $54(16.7)$ & $163(50.3)$ & 66.87 \\
\hline Identifies symptoms* & $23\left(\begin{array}{ll}7 & 1\end{array}\right)$ & $49(15.1)$ & $36(11.1)$ & $44(13.6)$ & $172(53.1)$ & 52.98 \\
\hline \multicolumn{7}{|l|}{ Pupil reaction } \\
\hline Uses mirror & $17(5.2)$ & $71(21.9)$ & $23(7.1)$ & $43(13.3)$ & $170(52.5)$ & 34.71 \\
\hline Ocular occlusion & $9(2.8)$ & $19(5.9)$ & $31(9.5)$ & $45(13.9)$ & $220(67.9)$ & 131.72 \\
\hline Evaluates pupil size & $6(1.9)$ & $14(4.3)$ & $22(6.8)$ & $48(14.8)$ & $234(72.2)$ & 151.90 \\
\hline Examines each eye & $9(2.8)$ & $12(3.7)$ & $15(4.6)$ & $44(13.6)$ & $244(75.3)$ & 149.25 \\
\hline \multicolumn{7}{|l|}{ Ocular movement } \\
\hline Follows luminous point & $8(2.5)$ & $12(3.7)$ & $15(4.6)$ & $38(11.7)$ & $251(77.5)$ & 151.90 \\
\hline Ocular movement & $13(4.0)$ & $8(2.5)$ & $6(1.8)$ & $35(10.8)$ & 262 (80.9) & 149.25 \\
\hline Records the result & $5(1.5)$ & $11(3.4)$ & $9(2.8)$ & $42(13.0)$ & $257(79.3)$ & 162.85 \\
\hline
\end{tabular}

$\chi^{2}$ : Chi-square; $\mathrm{p}$-value for all variables was < 0.005. TI: Totally inadequate; I: Inadequate; A: Adequate; PA: Partially adequate; TA: Totally adequate. Note: $\mathrm{n}=324$. 
The ocular movement exam had inadequacy of $6.5 \%$. It needs to be reviewed regarding the guidelines embedded on the virtual booklet, since it is difficult to follow the luminous point and properly move the eye. When considering the gold pattern, it can lead to a misjudgment about ocular movement conditions.

\section{DISCUSSION}

The reality in developing countries is a complex and diverse social context marked by financial difficulties. Although there are political proposals to detect visual problems, most are focal and expensive, without continuity, and do not ensure access to specialized consultations and corrective actions ${ }^{(9)}$. However, simple and cheap actions such as the ophthalmologic exam made by qualified personnel, in spite of not being specialists, allows the diagnosis and treatment of ocular conditions with early referrals for ophthalmologists ${ }^{(10)}$.

Studies conducted in different nations reveal that deficient knowledge in eye health care can contribute to the onset of blindness ${ }^{(11)}$. Globally, functional presbyopia affected 194.7 million people aged up to 35 years, and 666.7 million older than 50 years. The number of people with moderate and severe visual impairment also increased from 159.9 million in 1990 to 216.6 million in $2015^{(12)}$.

This contrasts with the evidence that early detection and the introduction of screening programs are part of the proactive clinical management required by the new requirements of care logic. These are proven to prevent visual loss and increase the survival of large numbers of people worldwide ${ }^{(13)}$.

Using the new proposal of the virtual booklet has evidently increased the conception that ocular health should be prioritized within the perspective of offering greater autonomy for subjects when performing the eye examination alone (by themselves).

Although it does not replace the ophthalmologist's evaluation, through observation of the state of visual health, the method proves to be easy to perform, and offers the chance of early identification of eye problems and reduction of health costs. Innovative practices that complement primary care actions are transforming care ${ }^{(14)}$.

However, there is greater concern with performing measures for increasing the knowledge on periodic evaluation of eye health. Results demonstrated the majority knows only of refractive errors and cataract as visual problems. Therefore, the proposal of eye self-examination is essential for enabling people to learn throughout life, and seek the development of personal skills. It is a task to be accomplished at schools, homes, workplaces and other community spaces ${ }^{(10)}$.

In this regard, the effective ocular health promotion involves a combination of a few components, namely, guided education for adoption of prevention measures, health service improvements, and a greater accessibility and expansion of public prevention policies on ocular disorders ${ }^{(15)}$. Half of children's blindness cases could be avoided with an early detection and by emphasizing educational strategies that benefit patients and help health professionals ${ }^{(16-17)}$.
Ophthalmology is one of the most propelled medical specialties by technology given the appearance of several resources allowing the detection and treatment of ocular diseases. With scientific knowledge, technologies and available treatments, about $80 \%$ of the world blindness is avoidable or curable. The tracking using Information and Communication Technologies is a strategy that tends to radically change the late detection overview of visual disabilities ${ }^{(18)}$.

The students said the virtual booklet on ocular self-exam enables awareness about eye care, and seems to be a favorable technology to be used on health education practices. A better understanding of educational preferences can help on the development of interventions and study material for the qualification of adults about ocular health ${ }^{(19)}$.

The aim of a study was to evaluate the learning preferences of patients attending an ophthalmologic clinic. It was found that most patients preferred individual sessions approaching ocular health themes with use of printed (36\%) and electronic (38\%) educational material ${ }^{(19)}$.

The self-exam investigates two fundamental parts: visual acuity and ocular structure evaluation, and supports individuals with the identification of visual disorders based on reference values. This method is comprehensive, easy to perform, can be used on the teaching of ocular exam and as an incentive to search for a doctor.

Visual acuity is, perhaps, the most known and important measure of visual function. Clinically, it is one of the vital signs of the eyes, and measured at a predetermined distance $^{(18)}$. In this study, visual acuity for long distances was measured through the Snellen scale. It was found that $66.4 \%$ of the students positioned the scale at the adequate distance.

Visual acuity can be checked quickly and at low cost by using cheap graphics available for printing or on digital environment ${ }^{(18)}$. The Snellen scale is the most common method for visual acuity measurement. It is related to factors such as the familiarity of professionals, well recognized punctuation system, adequate graphics size and testing speed ${ }^{(20)}$.

The degree of vision impairment, even if classified as mild, has a substantial effect on the quality of life. For example, in many countries, an individual with a vision level of $70 \%$ would be considered unfit for work duties ${ }^{(12)}$. The transforming effect of the method focuses on enabling the expansion of information with specialists in their health condition by serving as an alert.

The adequacy of steps accomplished by students was verified by comparison to the standard ocular exam determined according to the literature. Many of the exams had an adequacy percentage above $80 \%$, just like the visual acuity for near distances, eyelid and visual field evaluation.

Eyelid examination, which was adequately assessed by more than $82 \%$ of study participants, may aid in the identification of Graves' disease. This is an autoimmune condition recognized as a syndrome including an enlarged and overactive thyroid gland, an accelerated heart rate, and ocular abnormalities. The prevalence of problems includes retraction of the eyelids, proptosis, swelling of the eyelids and diplopia. This is followed by an inactive phase, in which ocular manifestations become stable ${ }^{(21)}$, hence the importance of continuous and periodic evaluation. 
Eye emergencies are a significant proportion of general emergency room visits. The red eye is one of the most common indicators that something in the eye is not going well. Different disorders can cause conjunctival infections, leading patients to seek emergency care. As the eye is a visible organ, it can show the first signs of local or systemic problems in the early stages of the disease ${ }^{(22)}$. According to results and adding the adequacy indexes, $87 \%$ of participants performed the examination of the eyelid satisfactorily with a suitability of $77.8 \%$ in the identification of the symptoms.

Examination of the pupillary reaction can provide subsidies for identifying cranioencephalic trauma, an important public health problem with socioeconomic burden worldwide. It is still considered one of the main causes of death and life incapacity, and has an estimated incidence at 700 to 100,000 people. Pupillary response is widely known as crucial for screening, prognosis, and guiding the subsequent management of patients with brain lesions and therefore, it is vital that their evaluation is accurate and reproducible ${ }^{(23)}$.

Not least, the evaluation of ocular movement with an adequacy index of more than $80.9 \%$ is fundamental for any ocular examination. It allows an evaluation of oculomotor behavior, changes in amplitude of the corneoretinal potential, and is useful mainly to detect nystagmus. Firstly, it is often important to check if the patient's nystagmus is present since childhood, hence the presumption that it either represents a stable neurological condition or is an acquired condition ${ }^{(24)}$.

The assessment of eye movement behavior is also clinically valuable in patients with bilateral central field loss. Most patients with bilateral central field loss have visual acuity using one or more peripheral retinal sites ${ }^{(24)}$. The condition in which the patient seeks the opposite direction from a peripherally presented stimulus has been reported in patients with Parkinson's disease and dementia due to neurodegenerative condition ${ }^{(25)}$.

So, it works as an enabler in the anchor process of new knowledge and cognitive organizer for providing the learning about addressed and autonomous discovery, and assimilating the learning of a different way from the traditional one $^{(26)}$. On the other hand, longitudinal studies are necessary for the evaluation of learning and behavioral adoption in order to affirm there was health promotion.

Although, a direct intervention was not held, as the monitoring through screens, it is argued that the ocular self-exam proposal can be incorporated on primary health care services, together with people's regular daily use. It is useful for identifying ocular problems in several situations, not only clinical but also traumatic ${ }^{(27)}$.

A study recently developed in India reached the conclusion on the possibility of promoting behavior changes when these include simple information and without involvement of complex procedures or those interfering with cultural beliefs ${ }^{(28)}$. Therefore, the need for information on ocular health justifies the efforts for greater possibility of access to knowledge about ocular self-care promotion.

Intervention studies are needed for helping with dissemination of the eye self-exam practice and encouragement of health professionals by providing more detailed information, including instructions about the ocular self-exam and proposals of periodic reminders for performing it.

\section{CONCLUSION}

The use of the virtual booklet was considered adequate. It can promote the ocular self-exam and optimize learning. These are very important results regarding a wide problem of visual health on a global scale.

Thus, care measures that prioritize the early identification of visual problems and promote self-care must be taken. The method simplicity and information linked to a wide access network can benefit the learning process and disseminate a new method for people and health professionals.

A proven method for assessing the visual condition by untrained individuals is relevant to clinical practice as it provides subjects' autonomy. The possibility of assessing one's health condition will likely increase the demand for specialized professionals and the eye health gains space in the list of periodical exams. Such behaviors displayed by subjects reinforce actions that promote visual health care in people's daily lives.

In managerial terms, there can be improvements in the follow-up of case management by following the public health current proposal. Thus, patients at risk of ocular involvement may benefit from remote monitoring by exchanging information with health professionals through their self-examination. This would increase the reach of public health promotion strategies.

The relevance of results reinforces the need for protecting the new method by patent for its practical application in actions of health promotion for the population. Future research is needed for demonstrating the practical applicability and people's adherence to the new method.

In general, studies on its applicability are part of a set of future-oriented research. In other words, only future research can prove that the knowledge of this new proposal will lead to the population's attitude and practice. Thus, such projections are considered viable given the results raised so far.

The lack of measure scales for diagnostic accuracy on ocular self-exams made the comparison of gold standard findings difficult, and posed itself as a study limitation.

\section{RESUMO}

Objetivo: Avaliar a prática do autoexame como uma ferramenta para promover a autoavaliação ocular. Método: Estudo quaseexperimental, desenvolvido em uma universidade do Piauí, com uma amostra de 324 estudantes, entre janeiro e maio de 2014, por uma equipe de 13 pesquisadores, os quais fizeram observações durante o autoexame seguido de uma triagem ocular. Resultados: Não houve concordância sobre a hipótese de que o exame ocular poderia ajudar a observar a saúde do olho ( $\mathrm{p}$-valor $>0,3$ ), no entanto, foi considerado de fácil realização $(99,7 \%)$, e que não só o médico pode realizá-lo $(99,4 \%)$. A conscientização do cuidado com os olhos é identificada como o principal objetivo do uso da cartilha $(97,6 \%),\left(\chi^{2}=186,01 ; p=0,001\right)$. O resultado destaca que o material educativo pode ser utilizado no processo de ensino do autoexame ocular $(84,6 \%)$. Embora a realização do autoexame não possa substituir a consulta com o oftalmologista $(23,8 \%),\left(\chi^{2}=46,34\right)$, ele deve ser feito rotineiramente $(82,4 \%)$. Conclusão: Os resultados comprovam que o aprendizado por meio de uma cartilha virtual é possível, apoiando o autocuidado com os olhos através da realização do autoexame. 
DESCRITORES

Olhos; Saúde Ocular; Autoexame; Educação em Saúde; Enfermagem em Saúde Pública.

\section{RESUMEN}

Objetivo: Evaluar la práctica del autoexamen como herramienta para promocionar la autoevaluación ocular. Método: Estudio cuasiexperimental, desarrollado en una universidad de Piauí, con una muestra de 324 estudiantes, entre enero y mayo de 2014, por un equipo de trece investigadores, quienes hicieron observaciones durante el autoexamen seguido de un cribado ocular. Resultados: No hubo concordancia acerca del supuesto de que el examen ocular podría ayudar a observar la salud ocular (valor-p >; 0,3). Sin embargo, se consideró como de fácil realización $(99,7 \%)$ y que no solo el médico puede llevar a cabo el examen ocular (99,4\%). Se identifica la concienciación acerca del cuidado ocular como la razón principal para el empleo de la cartilla $(97,6 \%),\left(\chi^{2}=186,01 ; p=0,001\right)$. El resultado subraya que el método educativo se puede utilizar en el proceso de enseñanza del autoexamen ocular (84,6\%). Aunque la realización del autoexamen no pueda reemplazar la consulta con el oftalmólogo $(23,8 \%),\left(\chi^{2}=46,34\right)$, se debe hacerlo de rutina $(82,4 \%)$. Conclusión: Los resultados comprueban que el aprendizaje mediante una cartilla virtual es posible, sosteniendo el autocuidado con los ojos mediante la realización del autoexamen.

\section{DESCRIPTORES}

Ojo; Salud Ocular; Autoexamen; Educación en Salud; Enfermería en Salud Pública.

\section{REFERENCES}

1. Lee P. Visual acuity screening among asymptomatic older adults. JAMA. 2016;315(9):875-76. DOI:10.1001/jama.2016.1271

2. Huberman AD, El-Danaf RN. Affiliations corresponding blindness: assassins of eyesight. Nature. 2015;527:456-57. DOI:10.1038/527456a

3. Takeda A, Baffi JZ, Kleinman ME, Cho WG, Nozaki M, Yamada K, et al. CCR3 is a target for age-related macular degeneration diagnosis and therapy. Nature. 2009;460(7252):225-30. DOI:10.1038/nature08151

4. Hayashi R, Ishikawa Y, Sasamoto Y, Katori R, Nomura N, Ichikawa T, et al. Co-ordinated ocular development from human iPS cells and recovery of corneal function. Nature. 2016;531(7594):376-80. DOI:10.1038/nature17000

5. Ahmad K, Zwi AB, Tarantola DJ, Chaudhry TA. Self-perceived barriers to eye care in a hard-to-reach population: the Karachi Marine Fishing Communities Eye and General Health Survey. Invest Ophthalmol Vis Sci. 2015;56(2):1023-32. DOI: 10.1167/iovs.14-16019

6. Bastawrous A, Rono HK, Livingstone IA, Weiss HA, Jordan S, Kuper H, et al. Development and Validation of a SmartphoneBased Acuity Test (Peek Acuity) for clinical practice and community-based fieldwork. JAMA Ophthalmol. 2015;133(8):930-7. DOI: 10.1001/jamaophthalmol.2015.1468.

7. Lima MA, Pagliuca LMF, Nascimento JC, Caetano JA. Virtual guide on ocular self-examination to support the self-care practice for people with HIV/AIDS. Rev Esc Enferm USP. 2014;48(2):281-7. DOI: http://dx.doi.org/10.1590/S0080-6234201400002000013

8. Lima MA, Pagliuca LMF, Nascimento JC, Caetano JA. Comparing interrater reliability between eye examination and eye self-examination. Rev Latino Am Enfermagem. 2017;25:e2966. DOI: http://dx.doi.org/10.1590/1518-8345.1232.2966

9. Petersen LR, Jamieson DJ, Powers AM, Honein MA. Zika Virus. N Engl J Med. 2016;374(16):1552-63. DOI:10.1056/NEJMc1607583

10. Kong X, Strauss RW, Michaelides M, Cideciyan AV, Sahel JA, Muñoz B, et al. Visual acuity loss and associated risk factors in the retrospective progression of stargardt disease study. Ophthalmology. 2016;123(9):1887-97. DOI: 10.1016/j.ophtha.2016.05.027.

11. Strain WD, Cos X, Hirst M, Vencio S, Mohan V, Vokó Z, et al. Time to do more: addressing clinical inertia in the management of type 2 diabetes mellitus. Diabetes Res Clin Pract. 2014;105(3):302-12. DOI: http://dx.doi.org/10.1016/j.diabres.2014.05.005

12. Bourne RRA, Flaxman SR, Braithwaite T, Cicinelli MV, Das A, Jost JB, et al. Magnitude, temporal trends, and projections of the global prevalence of blindness and distance and near vision impairment: a systematic review and meta-analysis. Lancet Glob Health. August 2 , 2017;5(9):e888-87. DOI: http://dx.doi.org/10.1016/S2214-109X(17)30293-0

13. Gale R, Scanlon PH, Evans M, Ghanchi F, Yang Y, Silvestri G, et al. Action on diabetic macular edema: achieving optimal patient management in treating visual impairment due to diabetic eye disease. Eye (Lond). 2017;31 Suppl 1:S1-S20. DOI:10.1038/eye.2017.53

14. Dale SB, Ghosh A, Peikes DN, Day TJ, Yoon FB, Taylor EF, et al. Two-year costs and quality in the comprehensive primary care initiative. N Engl J Med 2016;374(24):2345-56. DOI: 10.1056/NEJMsa1414953\#t=articleDiscussion

15. Peck JL. Social media in nursing education: responsible integration for meaningful use. J Nurs Educ. 2014;53(3):164-9. DOI:10.3928/01484834-20140219-03

16. Mandavilli A. Visual neuroscience: look and learn. Nature. 2006;441(7091):271-2. DOI: 10.1038/441271a

17. Vargas MA, Rodrigues MLV. Demand profile in an ophthalmologic primary care service. Rev Bras Oftalmol. 2010;69(2):77-83.

18. Saeedi OJ, Luzuriaga C, Ellish N, Robin A. Potential limitations of e-mail and text messaging in improving adherence in glaucoma and ocular hypertension. J Glaucoma. 2015;24(5):e95-e102. DOI:10.1097/IJG.0000000000000150

19. Rosdahl JA, Swamy L, Stinnett S, Muir KW. Patient education preferences in ophthalmic care. Patient Prefer Adherence. 2014;8:565-74. DOI:10.2147/PPA.S61505

20. Chou R, Dana T, Bougatsos C, Grusing S, Blazina I. Screening for impaired visual acuity in older adults: updated evidence report and systematic review for the US preventive Services task force. JAMA. 2016;315(9):915-33. DOI: 10.1001/jama.2016.0783

21. Smith TJ, Hegedüs L. Graves' disease. N Engl J Med. 2016;375(16):1552-65. DOI: 10.1056/NEJMra1510030

22. Tarff A, Behrens A. Ocular emergencies: red eye. Med Clin North Am. 2017;101(3):615-39. DOI: 10.1016/j.mcna.2016.12

23. Lee MH, Mitra B, Pui JK, Fitzgerald M. The use and uptake of pupillometers in the Intensive Care Unit. Aust Crit Care. 2017;pii:S1036-7314(16):30135-7. DOI: 10.1016/j.aucc.2017.06.003 
24. Bedell HE, Stevenson SB. Eye movement testing in clinical examination. Vision Res. 2013; 90:32-7. DOI: 10.1016/j.visres.2013.02.001

25. Stokholm MG, Iranzo A, Østergaard K, Serradell M, OttoM, Svendsen BK, et al. Assessment of neuroinflammation in patients with idiopathic rapid-eye-movement sleep behaviour disorder: a case-control study. Lancet Neurol. 2017;16(10):789-96. DOI: 10.1016/S14744422(17)30173-4

26. Smeltzer S, Colleen A, Haynor P. Original research: interactions of people with disabilities and nursing staff during hospitalization. AJN Am J Nurs. 2012;112(4):30-7. DOI: 10.1097/01.NAJ.0000413454.07369.e3

27. Gupta PC, Ram J. Eye injury from a firecracker. N Engl J Med. 2017;376(26):2579. DOI: 10.1056/NEJMicm1616104

28. Brady CJ, Eghrari AO, Labrique AB. Smartphone-based visual acuity measurement for screening and clinical assessment. JAMA. 2015;314(24):2682-3. DOI: 10.1001/jama.2015.15855 